\title{
Roughness analysis of composite based on aluminum alloys after electrical discharge machining process with use of different filtering methods
}

\author{
Zastosowanie wybranych metod filtracji w analizie chropowatości kompozytów \\ o osnowie ze stopu aluminium po obróbce elektroerozyjnej
}

\author{
ANETA ŁETOCHA \\ JOLANTA CYBOROŃ \\ TATIANA MILLER *
}

DOI: https://doi.org/10.17814/mechanik.2017.4.49

Ceramic materials or metallic materials containing ceramic phases are very interesting cases in roughness measurement. They are characterised by more or less pored surface. This paper presents roughness analysis of composite material with aluminum alloy base (AlSi7Mg) with 10 vol. \% of silicon carbide (SiC) and 10 vol. \% of spherical graphite $(\mathrm{Cg})$ additions. Surfaces of these samples were prepared using electrical discharge machining (EDM) process. Measurements were performed with use of contact TOPO 02 profilometer equipped with diamond stylus tip $(2 \mu \mathrm{m}$ radius and 60 degree cone angle). This machine is produced in The Institute of Advanced Manufacturing Technology. Measurements were analysed with use of three filtration methods: Gaussian filter, Robust Gaussian filter and Gaussian filter for surfaces having stratified functional properties. Height roughness parameters, roughness core parameters and volume parameters were calculated. Most proper filtering method, which gives credible results of roughness parameters, was chosen.

KEYWORDS: roughness analysis, filtration methods, EDM, aluminum composite

Materiały ceramiczne lub metaliczne zawierające fazy ceramiczne stanowią interesujący przypadek w pomiarach chropowatości powierzchni. Charakteryzują się bardziej lub mniej porowatą strukturą. Artykuł przedstawia analize chropowatości materiału kompozytowego o osnowie ze stopu aluminium (AlSi7Mg) zawierającego dodatek $10 \%$ obj. węglika krzemu (SiC) oraz 10\% obj. grafitu sferycznego (Cg). Powierzchnie próbek przygotowano z zastosowaniem obróbki elektroerozyjnej (EDM). Pomiary wykonano profilometrem stykowym TOPO 02 wyposażonym w głowicę indukcyjną z końcówką diamentową w kształcie stożka (promień: $2 \mu \mathrm{m}$, kąt wierzchołkowy: 60\%). Przyrzad produkowany jest w Instytucie Zaawansowanych Technologii Wytwarzania. Analizę wykonano trzema metodami filtracji: Gaussa, odpornej Gaussa oraz Gaussa dla powierzchni o warstwowych właściwościach funkcjonalnych. Obliczono parametry: wysokościowe, rdzenia chropowatości, objętościowe. Na podstawie wyników wybrano najlepszą metodę filtracji, dającą wiarygodne wyniki pomiaru parametrów chropowatości. SŁOWA KLUCZOWE: analiza chropowatości, metody filtracji, EDM, kompozyt o osnowie aluminiowej

\footnotetext{
* Mgr inż. Aneta Łętocha (aneta.letocha@ios.krakow.pl), mgr inż. Jolanta Cyboroń (jolanta.cyboron@ios.krakow.pl), mgr inż. Tatiana Miller (tatiana.miller@ios.krakow.pl) - Instytut Zaawansowanych Technologii Wytwarzania
}

Filters are an important way to separate insignificant features of measured surface from those which we are interested in. That is why filtration has always played a significant role in surface geometrical structure measurements. Depending on the tests purpose, filtration methods and algorithms should be selected in a conscious way. An unmatched filtration method improperly change the roughness parameters values. Ceramic materials or metallic materials containing ceramic phases are very interesting cases in roughness measurement. They are characterised by more or less pored surface. It means that in surface texture measurements they have more or less number of statistical deep valleys, which can be wide or very narrow. Results of calculated roughness parameters based on ceramic or metallic composite measurements after Gaussian filtration are mostly distorted. Therefore data obtained have been additionally analysed using filters: Gaussian filter for surfaces having stratified functional properties and Robust Gaussian regression filter.

Gaussian filtration is currently best-defined and most often used input data processing algorithm. It results among others from the fact, that Gauss filter is characterized by relatively easy calculating and interpretation method. It does not show phase shifting and ringing effect. In Gaussian filtration long wavelengths components transmission characteristic is determined on the basis of Fourier transform of weighting function. Short wavelength components transmission characteristics is a compliment [1-3]. Gaussian filter for surfaces having stratified functional properties (valley suppression filter) and Robust Gaussian filter are based on Gaussian filter algorithms and principles of operation, but should be robust. It means that they are insensitive on input profile discontinuities as: slope, step and spike (sudden hills or dales). Valley suppression filter is less robust than Robust Gaussian regression filter [4-5].

\section{Samples, measurement and analysis method}

The aluminum matrix composite AISi7Mg with 10 vol. \% of silicon carbide particles and $10 \mathrm{vol}$. \% of $\mathrm{Cg}$ (spherical graphite), as a tested material was chosen in these paper. The initial phase composition of aluminum matrix was: $6.5 \div 7.5 \mathrm{Si}, 0.55 \mathrm{Fe}, 0.2 \mathrm{Cu}, 0.35 \mathrm{Mn}, 0.2 \div 0.65 \mathrm{Mg}, 0.154$ $\mathrm{Zn}$, the rest is $\mathrm{Al}$ [wt\%]. Metal matrix composite containing heterophase $\mathrm{SiC}$ and $\mathrm{Cg}$ reinforcement, was obtained by 
stir casting (suspension) method. Methods of manufacturing of this composite were described in [6-8]. The samples were machined using an electrical discharge method (EDM) with EWEA 40CNC device, electrodes made of brass and $\mathrm{Zn}$ with central diameter $0.25 \mathrm{~mm}$. Deionized and filtered water was used as dielectric. Each worked sample had deltoid shape (fig. 1).

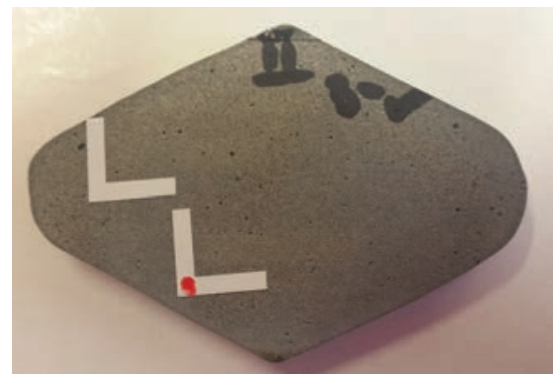

Fig. 1. Tested sample

Three different EDM machining processes were performed in Department of Erosion and Grinding Techniques of The Institute of Advanced Manufacturing Technology. Measurements were done with use of contact profilometer - TOPO 02. The machine was equipped with diamond stylus tip with $2 \mu \mathrm{m}$ radius and 60 degree cone angle. This machine is produced in The Institute of $\mathrm{Ad}$ vanced Manufacturing Technology. Three samples were measured. Two start points for $12.5 \times 3 \mathrm{~mm}$ measurement area were assigned on each one. Measurement analysis contained: different filtration methods (Gaussian filter, Robust Gaussian filter and Gaussian filter for surfaces having stratified functional properties), selected surface texture ( $\mathrm{Sa}$ - arithmetical mean height of the surface, $S p$ - maximum peak height of the surface, $S v$ - maximum pit height of the surface, $S z$ - maximum height of the surface, Svk - reduced pit height, $V v v$ - dale void volume of the surface, $V v c$ - core void volume of the surface) and roughness profile ( $R a$ - arithmetical mean height of the profile, $R p$ - mean hill height of the profile, $R v-$ mean dale height of the profile, $R z$ - mean of maximum heights of the profile, $R t$ - maximum height of the profile, Rvk reduced dale height) parameters analysis. Changes of the results of roughness surface and profile parameters, in dependence of used filtration method, were analysed. Most proper filtering method was chosen.

\section{The results}

Figure 2 presents example of measured surface after use of three filtration methods: Gaussian filter, Gaussian filter for surfaces having stratified functional properties, Robust Gaussian filter.

In fig. 2 effect of Gaussian filter and Gaussian filter for surfaces having stratified functional properties usage is clearly visible - surface raising near deep dales, which influence on height value of hills and dales.

Table I presents results of selected height roughness surface parameters, calculated after different filtration methods. Designation in tables I-III: G - Gaussian filter used in roughness analysis, SG - Gaussian filter for surfaces having stratified functional properties used in roughness analysis, RG - Robust Gaussian filter used in roughness analysis. Figure 3 presents how results of $\mathrm{Sa}[\mu \mathrm{m}]$ and $S p[\mu \mathrm{m}]$ parameters change in dependence of used filtration method. Sa parameter values are changing without dependence of selected filtration method. Results of $\mathrm{Sp}$ parameter decrease with increase of robustness of used
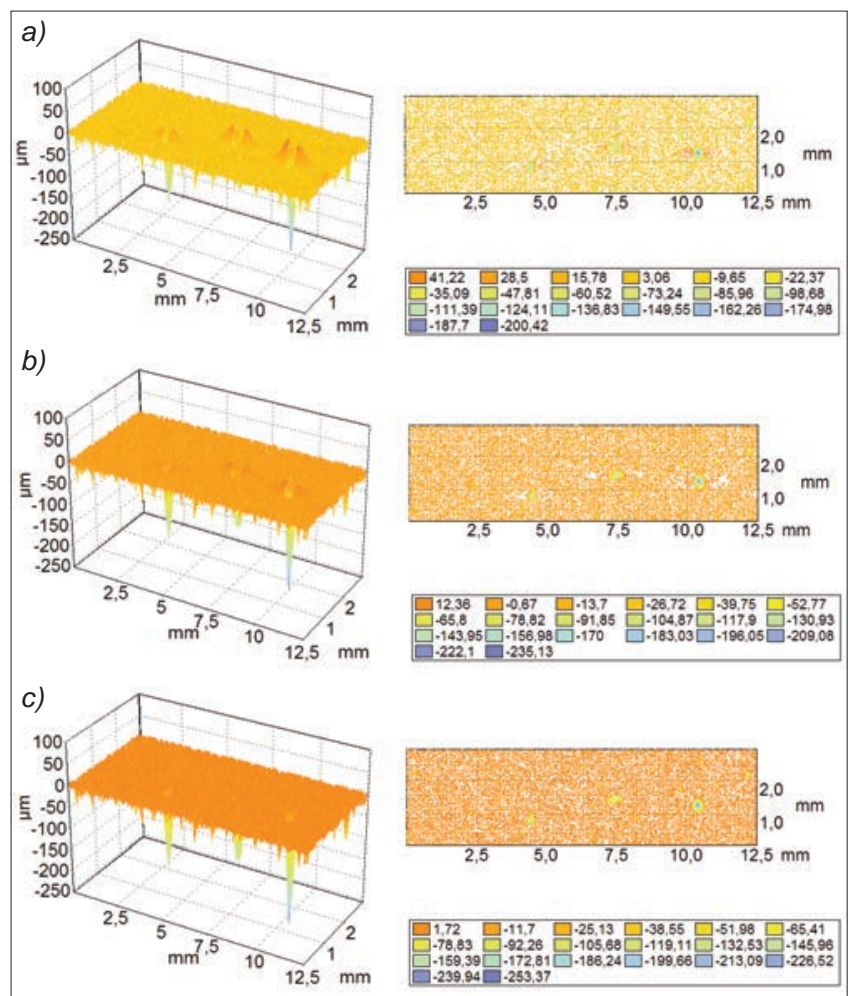

Fig. 2. Stereometric graphs and contour maps of surface II-2: a) Gaussian filter used, b) Gaussian filter for surfaces having stratified functional properties used, c) Robust Gaussian filter used

filtration method. It is caused by false hills which appears after non-robust filtration. Results after Gaussian filtration are significantly higher than after other used filtration methods. Difference between results is mostly visible for II-2 area which contains the biggest dale. In the case of Sv and $S z$ parameters the highest values are for the most robust filtration method - no distortion of the surface is the reason. For few measurement areas results after Robust Gaussian filtration are similar to results after valley suppression filtration. Table II presents results of other roughness surface parameters, calculated after different filtration methods. For $V v v$ parameter results increase with robustness of the filter, for $V v c$ parameter results situation is invert.

TABLE I. Results of selected height roughness surface parameters, calculated after different filtration methods

\begin{tabular}{|c|c|c|c|c|c|c|c|}
\hline \multirow{2}{*}{ Parameter } & \multirow[b]{2}{*}{ Filter } & \multicolumn{6}{|c|}{ Sample } \\
\hline & & |-1 & $1-2$ & II-1 & II-2 & III-1 & III-2 \\
\hline \multirow{3}{*}{$\mathrm{Sa}, \mu \mathrm{m}$} & $G$ & 4.89 & 4.55 & 4.42 & 5.29 & 5.38 & 5.28 \\
\hline & SG & 4.94 & 4.69 & 4.42 & 5.12 & 5.54 & 5.45 \\
\hline & $R G$ & 4.87 & 4.57 & 4.41 & 5.12 & 5.41 & 5.32 \\
\hline \multirow{3}{*}{$S p, \mu \mathrm{m}$} & $G$ & 33.27 & 30.02 & 32.58 & 55.17 & 25.34 & 24.39 \\
\hline & SG & 17.56 & 17.39 & 19.55 & 26.65 & 21.62 & 18.02 \\
\hline & $R G$ & 17.91 & 19.09 & 21.54 & 15.15 & 24.24 & 21.50 \\
\hline \multirow{3}{*}{$S v, \mu \mathrm{m}$} & $G$ & 141.65 & 87.38 & 99.45 & 200.88 & 112.66 & 68.84 \\
\hline & SG & 162.82 & 99.88 & 112.99 & 235.59 & 126.60 & 75.22 \\
\hline & $R G$ & 168.34 & 101.69 & 112.89 & 253.83 & 128.94 & 73.47 \\
\hline \multirow{3}{*}{$S z, \mu \mathrm{m}$} & $G$ & 174.92 & 117.41 & 132.03 & 256.05 & 138.00 & 93.23 \\
\hline & SG & 180.38 & 117.27 & 132.54 & 262.24 & 148.22 & 93.24 \\
\hline & $R G$ & 186.25 & 120.78 & 134.43 & 268.98 & 153.17 & 94.98 \\
\hline
\end{tabular}

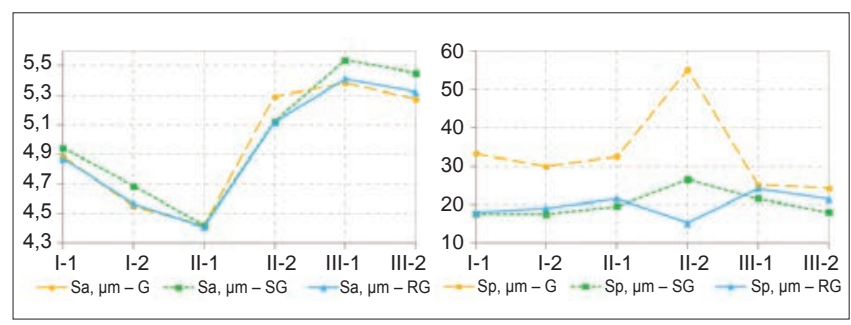

Fig. 3. Changes of the results of $S a[\mu \mathrm{m}]$ and $S p[\mu \mathrm{m}]$ roughness surface parameters, in dependence of filtration method used 
One can see that for measurement areas having deep, but narrow dales Gaussian filter for surfaces having stratified functional properties and Robust Gaussian filter have similar results of roughness surface parameters and both did not distort area near dales. In case of wide and deep dales like in II-2 measurement area, only Robust Gaussian filter gives proper and not distorted results.

TABLE II. Results of selected roughness surface parameters, calculated after different filtration methods

\begin{tabular}{|c|c|c|c|c|c|c|c|}
\hline \multirow{2}{*}{ Parameter } & \multirow{2}{*}{ Filter } & \multicolumn{6}{|c|}{ Sample } \\
\hline & & $1-1$ & $1-2$ & II-1 & II-2 & III-1 & III-2 \\
\hline \multirow{3}{*}{$S v k, \mu \mathrm{m}$} & $G$ & 15.18 & 11.63 & 15.37 & 22.66 & 12.49 & 12.632 \\
\hline & $S G$ & 16.02 & 12.24 & 15.82 & 24.55 & 13.33 & 13.285 \\
\hline & $R G$ & 16.58 & 12.19 & 16.59 & 26.18 & 13.38 & 13.359 \\
\hline \multirow{3}{*}{$V v v, \mathrm{ml} / \mathrm{m}^{2}$} & $G$ & 1.24 & 1.01 & 1.24 & 1.71 & 1.15 & 1.158 \\
\hline & SG & 1.33 & 1.08 & 1.35 & 1.94 & 1.21 & 1.217 \\
\hline & $R G$ & 1.35 & 1.07 & 1.38 & 2.04 & 1.21 & 1.198 \\
\hline \multirow{3}{*}{$V v c, \mathrm{ml} / \mathrm{m}^{2}$} & $G$ & 6.11 & 6.01 & 5.18 & 5.57 & 7.21 & 7.001 \\
\hline & SG & 5.94 & 5.82 & 4.99 & 5.13 & 7.00 & 6.898 \\
\hline & $R G$ & 5.93 & 5.94 & 5.03 & 5.15 & 7.12 & 7.059 \\
\hline
\end{tabular}

TABLE III. Results of selected height roughness surface parameters, calculated after different filtration methods

\begin{tabular}{|c|c|c|c|}
\hline \multirow{2}{*}{ Parameter } & \multirow{2}{*}{ Filter } & \multicolumn{2}{|c|}{ Sample } \\
\cline { 2 - 4 } & & II-1 & II-2 \\
\hline \multirow{3}{*}{$R a, \mu \mathrm{m}$} & $G$ & 4.488 & 5.504 \\
\cline { 2 - 4 } & SG & 4.524 & 5.634 \\
\cline { 2 - 4 } & $R G$ & 4.592 & 5.802 \\
\hline \multirow{3}{*}{$R p, \mu \mathrm{m}$} & $G$ & 12.085 & 14.229 \\
\cline { 2 - 4 } & $S G$ & 11.579 & 12.098 \\
\cline { 2 - 4 } & $R G$ & 11.771 & 11.620 \\
\hline \multirow{3}{*}{$R v, \mu \mathrm{m}$} & $G$ & 30.728 & 41.128 \\
\cline { 2 - 4 } & $S G$ & 31.878 & 43.749 \\
\cline { 2 - 4 } & $R G$ & 32.133 & 44.877 \\
\hline
\end{tabular}

Results of selected roughness profile parameters are presented in table III. Figure 4 presents examples of roughness, waviness and primary profiles of surface II-2 after use of different filtering methods. In the figures presenting
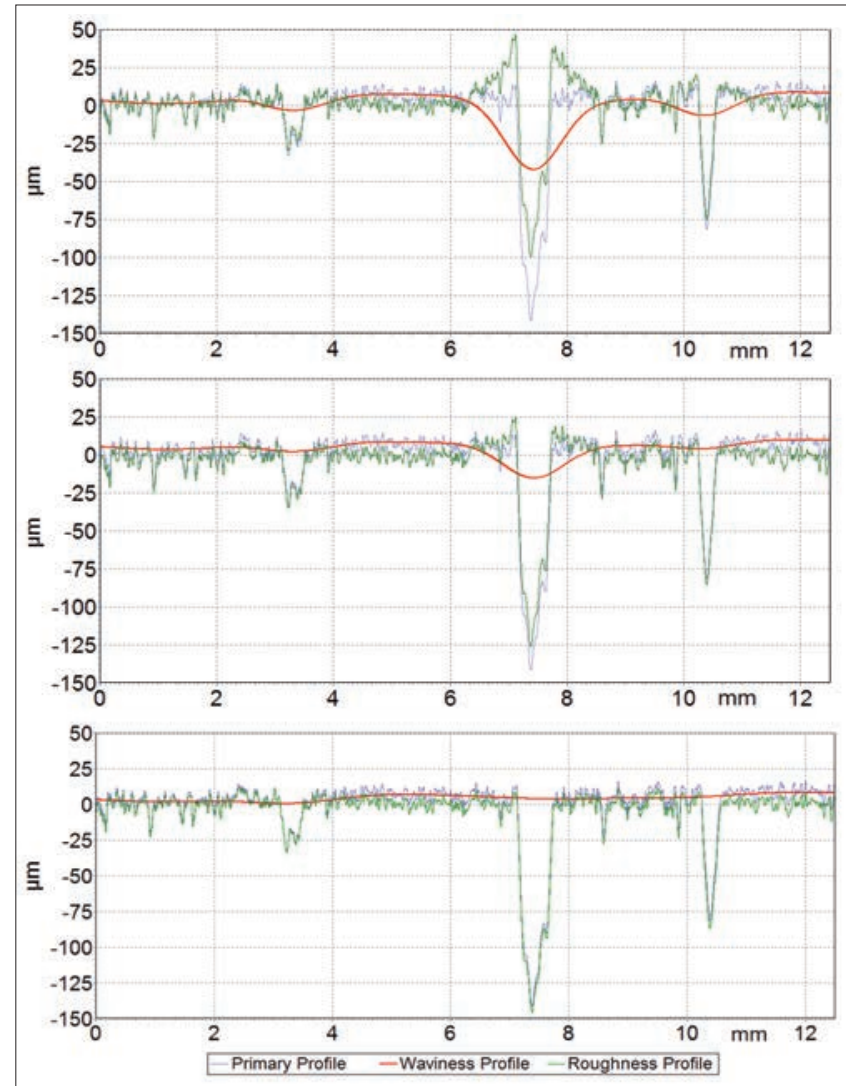

Fig. 4. Roughness, waviness and primary profiles of surface II-2 after use of three filtering methods - respectively: Gaussian filter, Gaussian filte for surfaces having stratified functional properties, Robust Gaussian filter primary, waviness and roughness profiles after selected filtration methods (fig. 4) one can see how robustness of filtration method influence on profile measurements. In waviness profile characteristic dales and distortion near them are visible for less robust filters. Parameters which values increase with filtration robustness increasing are: $R a$ and $R v$, only values of $R p$ parameter decrease (tab. III).

\section{Conclusions}

In accordance with ISO standards, filtration is essential to roughness surface and profile analysis. In case of metallic composite surfaces machined using an electrical discharge method (EDM), taking into account shape of surface texture, the most proper for analysis is Robust Gaussian filter which allows to obtain credible and not distorted information about roughness of the samples. If samples do not have many big open pores, and so valleys are deep, but narrow it is acceptable to use Gaussian filter for surfaces having stratified functional properties.

Surface and profile roughness parameters related with hills evaluation decrease with increasing of robustness of used filtration method. Standard Gaussian filter and Gaussian filter for surfaces having stratified functional properties underestimates roughness parameters related with dales, and overstates those related with hills. Differences in roughness parameters results between standard Gaussian filter and Robust Gaussian filter are equal even up to $264 \%$. Differences in roughness parameters results between Gaussian filter for surfaces having stratified functional properties and Robust Gaussian filter are equal even up to $75 \%$.

Results of surface and profile roughness parameters related with dales and amplitude evaluation increase with increasing of robustness of filtration method used.

Part of the study constitutes a part of the project no. PBS2/A6/20/2013/NCBiR/24/10/2013 "Research and evaluation of reliability of modern methods of surface topography measurements in micro- and nanoscale".

\section{REFERENCES}

1. Dobrzański P., Pawlus P. "Modification robust filtering of stratified surface topography". Metrology and Measurement Systems. Vol. XX, No. 1 (2013): pp. 107-118.

2. Dobrzański P., Pawlus P. "Digital filtering of surface topography: Part I. Separation of one-process surface roughness and waviness by Gaussian convolution, Gaussian regression and spline filters". Precision Engineering. 34 (2010): pp. 647-650.

3. Łętocha A., Miller T., Gajda K. "Influence of different filtration methods application on a filtered surface profile and roughness parameters". Key Engineering Materials. Vol. 637 (2015): pp. 57-68.

4. Dobrzański P., Pawlus P. "Digital filtering of surface topography: Part II. Applications of robust and valley suppression filters". Precision Engineering. 34 (2010): pp. 651-658.

5. Scott P.J., Jiang X.Q., Blunt L.A. "An overview of the relationship between approximation theory and filtration". Algorithms For Approximation IV. Proceedings of the 2001 International Symposium. (2001): pp. 188-195.

6. Dolata A.J., Dyzia M. "Aspects of fabrication aluminium matrix heterophase composites by suspension method". Materials Science and Engineering. Vol. 35, pp. 1757-8981. DOI:10.1088/1757$-899 \times / 35 / 1 / 012020$

7. Dyzia M. "AISi7Mg/SiC and heterophase $\mathrm{SiC}(\mathrm{p})+\mathrm{C}(\mathrm{g})$ composite for use in cylinder-piston system of air compressor". Light Metals and Their Alloys I: Technology, Microstructure and Properties. Book Series: Solid State Phenomena. Vol. 176, pp. 49-54. DOI: 10.4028/ www.scientific.net/SSP.176.49.

8. Wieczorek J., Dyzia M., Dolata A.J. "Machinability of aluminium matrix composites". Light Metals and Their Alloys II: Technology, Microstructure and Properties. Book Series: Solid State Phenomena. Vol. 191, pp. 75-80, DOI: 10.4028/www.scientific.net/SSP.191.75. 